\title{
DEVELOPMENT OF INVERSE CAMBIA AND STRUCTURE OF SECONDARY XYLEM IN IPOMOEA TURBINATA (CONVOLVULACEAE)
}

\author{
KISHORE S. RAJPUT
}

\begin{abstract}
Structural transformation of mechanical tissues during the shift from a freestanding to a climbing habit is a characteristic of lianas, which are increasingly abundant in tropical forests. The modification of mechanical tissue and the evolution of a new growth pattern serve to increase stem flexibility and conductive efficiency. In Ipomoea turbinata Lag. (Convolvulaceae), the stem thickens via the formation of two distinct types of successive cambia: functionally normal successive cambia (producing xylem centripetally and phloem centrifugally), and inverse cambia (producing xylem centrifugally and phloem centripetally). The former originates from pericyclic derivatives (parenchyma cells located outside the primary phloem), while the latter originates from the conjunctive parenchyma located on the inner margin of the secondary xylem formed from vascular cambium. The secondary xylem produced by normal cambia is significantly more abundant than the xylem formed by inverse cambia. During primary growth, intraxylary primary phloem differentiates concomitantly with the protoxylem at the periphery of the pith; additional intraxylary secondary phloem is added from adjacent parenchyma cells as the plant ages. During initiation of every successive cambium, middle cells in the meristem give rise to cambium, and cells on either side of it serve as sites for initiation of future cambia. The functional role of inverse cambia remains unknown and awaits further experimental studies.
\end{abstract}

Key words: cambial variant, Convolvulaceae, interxylary phloem, intraxylary phloem

Kishore S. Rajput, Department of Botany, Faculty of Science, The Maharaja Sayajirao University of Baroda, Vadodara-390 002 , India; e-mail: ks.rajput15@yahoo.com

\section{INTRODUCTION}

The increase in the abundance of non-freestanding plants (lianas) in tropical forests is associated with their ability to adjust to ecoclimatic conditions. Their increasing abundance may be correlated with anthropogenic pressure on forest ecosystems, their fragmentation, changes in land use patterns, increased atmospheric $\mathrm{CO}_{2}$ and evapotranspiration demand (Schnitzer \& Bongers 2011). During the shift from a freestanding to a climbing habit, they undergo several modifications of their mechanical tissue and the patterns of secondary thickening. Among them, the formation of successive cambia is most prevalent in climbing species, a process rare in trees and reported in Avicennia marina (Forssk.) Vierh, Phytolacca dioca L., Salvadora persica L. and Gallesia integrifolia (Spreng.) Harms (Carlquist 2001; Robert et al. 2011; Rajput et al. 2012a). The occurrence of successive cambia, although reported in several species (Schenck 1893; Pfeiffer 1926; Chalk \& Chattaway 1937; Metcalfe \& Chalk 1950; Obaton 1960; Lowell \& Leucasky 1986; Carlquist 2001; Rajput et al. 2008, 2012a, 2013), is restricted to a small group of dicotyledonous taxa (Carlquist 2001). Their formation in dicotyledons is said to be a derived character which represents a variant pathway of secondary tissue production, while normal cambium is ancestral (Carlquist 2001). It provides tensile strength and protects the xylem from malfunction of conductive elements in response to injury (Rajput et al. 2012b). Each successive ring of secondary xylem acts as a subunit which allows conduction of water and mineral nutrients among all units even when some units are injured (Fisher \& Ewers 1991; Rajput et al. 2012b).

The origin of successive cambia varies from species to species. They may develop from the 
pericycle, endodermis or cortical parenchyma, or may form as a result of the irregular activity of normal cambium, such as the formation of included phloem or grooved or irregularly shaped stems (Carlquist 2001; Rajput et al. 2012b; Terrazas et al. 2011). Besides these types of origin, the notion of master cambium has been proposed (Carlquist 2007, 2013), according to which cessation of cell division activity in vascular cambium results in the appearance of master cambium outside the secondary phloem by tangential divisions in the cortical parenchyma (Carlquist 2004, 2007, 2013). This newly initiated meristem is the master cambium that produces conjunctive tissue on the inner side and vascular cambium on the periphery of newly formed conjunctive tissue (Carlquist 2007, 2013). The master cambium usually forms secondary xylem centripetally (towards the pith) and secondary phloem centrifugally (towards the periphery). In my present study, however, the successive cambia not only differed in their origin but also deviated from the normal pattern of functioning.

Most earlier studies on the Convolvulaceae have used dry wood samples or have focused on the typical and frequently observable anatomical characteristics of the family (Schenck 1893; Pfeiffer 1926; Chalk \& Chattaway 1937; Metcalfe \& Chalk 1950; Obaton 1960; Lowell \& Leucansky 1986; Carlquist \& Hanson 1991; Rajput et al. 2008, 2013; Terrazas et al. 2011). There are few reports of the occurrence of functionally inverse cambia, and virtually no information in the literature on such a unique pattern of secondary growth. Earlier works have described the occurrence of successive cambia in the form of interand intraxylary phloem, a characteristic feature of the family Convolvulaceae. Initiation of small segments of inverse cambia has been reported in Dolichos lablab L. and in other species of Ipomoea L. (Rajput et al. 2006, 2008; Terrazas et al. 2011). Patil et al. (2009) and Terrazas et al. (2011) observed the origin of internal cambium at the pith margin and the development of intraxylary phloem from the pith margin in other species of Ipomoea. The present paper also reports the formation of inverse cambia in Ipomoea turbinata Lag.
With a view toward advancing our knowledge of the anatomy and taxonomy of vines, I studied the development of functionally normal and inverse successive cambia, the formation of intraxylary phloem, and the structure and development of secondary xylem from both cambial types in Ipomoea turbinata.

\section{MATERIALS AND METHODS}

Samples from main stems $8-25 \mathrm{~mm}$ thick and 40-60 mm long were collected from ten plants of Ipomoea turbinata Lag. (Convolvulaceae) growing at Bhorkheda $\left(21^{\circ} 18^{\prime} 27.40^{\prime \prime} \mathrm{N}, 74^{\circ} 58^{\prime} 49.02^{\prime \prime} \mathrm{E}\right)$ in Maharashtra State and at Bordevi, Girnar forest $\left(21^{\circ} 28^{\prime} 47.38^{\prime \prime} \mathrm{N}, 70^{\circ} 32^{\prime} 12.76^{\prime \prime} \mathrm{E}\right)$, Gujarat State; 8-10 segments from main stems were collected at various heights (ground level, $30 \mathrm{~cm}$ above ground, 2-3 m above ground, apex of plant). For primary growth, samples at various developmental stages (starting from the apical tip to $1 \mathrm{~m}$ away from it) were collected and fixed immediately in formaldehyde-acetic acid-alcohol (FAA) (Berlyn \& Miksche 1976). After fixation for $24 \mathrm{~h}$, samples were transferred to $70 \%$ alcohol for further processing and storage. Samples for primary growth were trimmed to $1-2 \mathrm{~mm}$ pieces and dehydrated through a tertiary butyl alcohol (TBA) series and processed for paraffin embedding as described by Johansen (1940). Thick stem samples were sectioned in various planes directly on a sliding microtome (Leica SM2010R), and paraffin blocks were cut with a rotary microtome (Leica RM 2035). Sections $15-20 \mu \mathrm{m}$ thick were cut in transverse, radial and tangential longitudinal planes and stained with safranin fast green (Johansen 1940). Slides were dehydrated through an ethanol-xylene series and mounted in dibutyl phthalate xylene (DPX). Micrographs of important results were made with a Leica DME 2000 trinocular photomicroscope fitted with a Canon S70D digital camera.

Dimensional details of the sieve tube elements were measured directly from the tangential longitudinal sections. Length and width of xylem fibres and wider and fibriform vessel elements were measured from macerated xylem. For maceration, small pieces of xylem portions adjacent to the outermost cambial ring were sliced and treated with Jeffrey's fluid (Berlyn \& Miksche 1976) at $55-60^{\circ} \mathrm{C}$ for $24-36 \mathrm{~h}$ and stained with $1 \%$ aqueous solution of safranin. Means and standard deviations were calculated from 30 random measurements. 


\section{RESULTS}

\section{DEVELOPMENT OF VASCULAR CAMBIUM}

At the $7^{\text {th }}$ internode, the first ring of vascular cambium is formed by fascicular segments of several conjoined collateral vascular bundles connected by interfascicular cambium. At this stage, discrete strands of intraxylary phloem are observed as distinct clusters at the periphery of the pith. This first ring of vascular cambium functions as it does in other dicots, producing secondary xylem centripetally and secondary phloem centrifugally. The secondary phloem is composed of sieve tubes, companion cells, and axial and ray parenchyma cells. The secondary xylem consists of wider vessels, fibriform vessels, fibre tracheids, tracheids and xylem parenchyma cells. At this stage the protoxylem remains unchanged, while the clusters of intraxylary phloem increase in number due to differentiation of additional sieve tube elements from adjacent cells and development of internal cambium (Fig. 1). As in other members of the Convolvulaceae, the vascular cambium of I. turbinata develops the next new ring of cambium after producing $3-5 \mathrm{~mm}$ of secondary xylem.

\section{DEVELOPMENT OF SUCCESSIVE CAMBIA}

The first successive ring of cambium initiates after cessation of cell division in the vascular cambium. This newly formed ring of cambium initiates as several small segments from parenchymatous derivatives of the pericycle located outside the protophloem (Fig. 2A). Prior to initiation of new cambium, one or two cell layers of parenchyma cells undergo repeated periclinal divisions, resulting in the formation of a wide 3-4-layer band of meristematic cells arranged in radial files (Fig. 2B, C). The cells in the middle of the meristematic band divide further and form a new segment of cambium, while the cells on either side of the cambium serve as sites for the imminent development of new cambia (Fig. 2D). This newly formed cambium is functionally bidirectional, producing secondary xylem centripetally and phloem centrifugally (Fig. 2E). Each functionally normal successive cambium follows

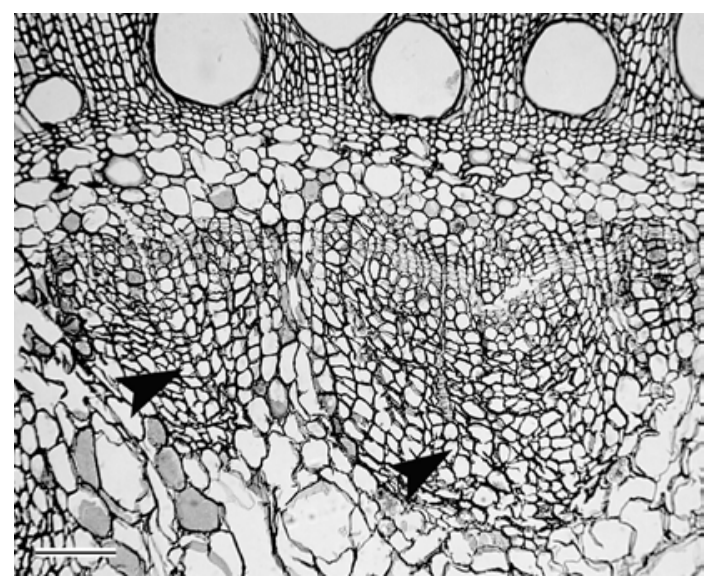

Fig. 1. Transverse view of thicker stem, showing increased number of intraxylary phloem cells (arrowheads). Scale bar $=500 \mu \mathrm{m}$.

a similar pattern of initiation. The first two or three successive cambia form a continuous cylinder; thereafter, each new cambium initiates as several small segments (Fig. 2F) which later became interconnected to form a complete ring. These newly formed cambial segments produce conducting elements of secondary xylem and phloem on either side. After a few xylem and phloem derivatives form, the cells between adjacent cambial segments become meristematic and differentiate exclusively into thin-walled parenchyma (conjunctive tissue) cells on the outer and inner sides.

\section{ORIGIN OF FUNCTIONALLY INVERSE CAMBIA}

In thicker stems, when the third ring of cambium completes the formation of 15-20 xylem derivatives, the parenchyma cells on the adaxial side of the xylem formed by the second cambial ring dedifferentiate, forming a 3-4-cell-wide band of radially arranged cells which redifferentiate into radially arranged meristematic cells (Fig. 2F). This newly originated cambium divides bidirectionally, producing xylem centrifugally and phloem centripetally (Fig. 3A, B). Before cell division ceases in the outermost cambial ring, functionally inverse cambium produces 20-25 xylem derivatives and 8-10 phloem elements. The development of more inverse cambia follows a similar pattern of origin. As in functionally normal cambia, inverse cambia 
also originate as small segments (Fig. 3C-E). In these cambia, differentiation of the conducting elements of secondary xylem and phloem remains restricted to a small portion, while alternating segments exclusively produce thin-walled parenchyma cells (Fig. 3E). Thick stems studied in the present work show eight rings of cambia, five of which are functionally normal, producing secondary xylem centripetally and phloem centrifugally; the other three cambia form secondary xylem centrifugally and phloem centripetally (Fig. 4A-C). The fourth cambium is initiated on the inner margin of the secondary xylem of the outermost cambium ring.

\section{STRUCTURE OF SECONDARY XYLEM}

The secondary xylem is diffuse-porous with indistinct growth rings, and composed of markedly wider and narrower fibriform vessels (Fig. 4A, B). In transverse view it is difficult to distinguish the narrower vessels; their narrow diameter makes them resemble fibres and axial parenchyma cells. No significant difference in secondary xylem structure between normal and inverse cambia was observed, except that more secondary xylem was produced by functionally normal than by inverse cambia. Axial parenchyma cells are sparsely vasicentric and thick-walled; islands of thin-walled parenchyma are randomly distributed. Thick-walled parenchyma cells are intermixed with fibres, and some of them form a sheath around vessels.

The vessels are 437-498 $\mu \mathrm{m}$ long and 134$260 \mu \mathrm{m}$ wide, mostly solitary, with a simple perforation plate on transverse-end walls. The alternate bordered pits on their lateral walls are oval to elliptic, oblong, and 7-10 $\mu \mathrm{m}$ in diameter. The occurrence of tyloses in wider vessels is a common feature in all successive rings; the tyloses are mostly thin-walled. As in other
Convolvulaceae, the fibriform vessel elements are fusiform cells which look like tracheids except for the presence of a small subterminal simple perforation plate near the end of the cells. They are 478-518 $\mu \mathrm{m}$ long and 28-34 $\mu \mathrm{m}$ wide. The xylem rays are mostly uniseriate to biseriate; multiseriate rays occur infrequently. The conjunctive tissues are built of thin-walled, unlignified parenchyma cells which form a band of six or seven cells, serving as a site for the development of inverse cambium.

Discrete strands of intraxylary (internal) phloem are also observed on the periphery of the pith. Its development is synchronous with that of protophloem, and distinct strands are observed by the time secondary growth starts. Additional intraxylary (internal) phloem is added from adjacent cells, which are larger than the pith cells. As secondary growth progresses, cambial action occurs on the pith margin. Nonconducting phloem degrades and accumulates on its inner margin. Like external phloem, intraxylary phloem is composed of sieve elements, companion cells, and axial and ray parenchyma cells.

\section{DisCUSSION}

Cambial variants have been reported in several genera of different families of dicotyledons, described in a number of extensive monographs (e.g., Schenk 1893; Metcalfe \& Chalk 1950; Obaton 1960; Carlquist 2001); they pose problems in classification, in interpretation, and even in establishing their origin (Carlquist 2001). Numerous classifications of these growth patterns have been proposed, most of them failing to encompass all variant types (e.g., Carlquist 2001). According to Carlquist (2001), the cambial variants reported so far may be grouped into three main classes: $(i)$ successive cambia producing

Fig. 2. Transverse view of young stem of Ipomoea turbinata Lag., showing various stages of initiation of successive cambia. A - Initiation of cell division and formation of wide band of meristematic cells (arrows) outside of crushed protophloem (arrowhead). B - Enlarged view of A, showing wide band of radially arranged meristematic cells (arrowhead). Note the tangentially flattened endodermis (E) and crushed protophloem (arrow). C - Newly established cambial segment, showing radially arranged cells (arrowhead) and differentiating vessel (arrow). D - Cells on either side (arrowheads) of cambium, serving as sites for initiation of future cambium. Note the differentiating xylem derivatives and phloem elements opposite to it. E - Bidirectional differentiation of secondary xylem $(\mathrm{X})$ and phloem element (arrowhead). $\mathrm{V}$ - vessel, $\mathrm{F}$ - newly initiating functionally inverse cambium (arrowhead). Scale bars: A \& F $=300 \mu \mathrm{m} ; \mathrm{B}-\mathrm{D}=50 \mu \mathrm{m} ; \mathrm{E}=200 \mu \mathrm{m}$. 

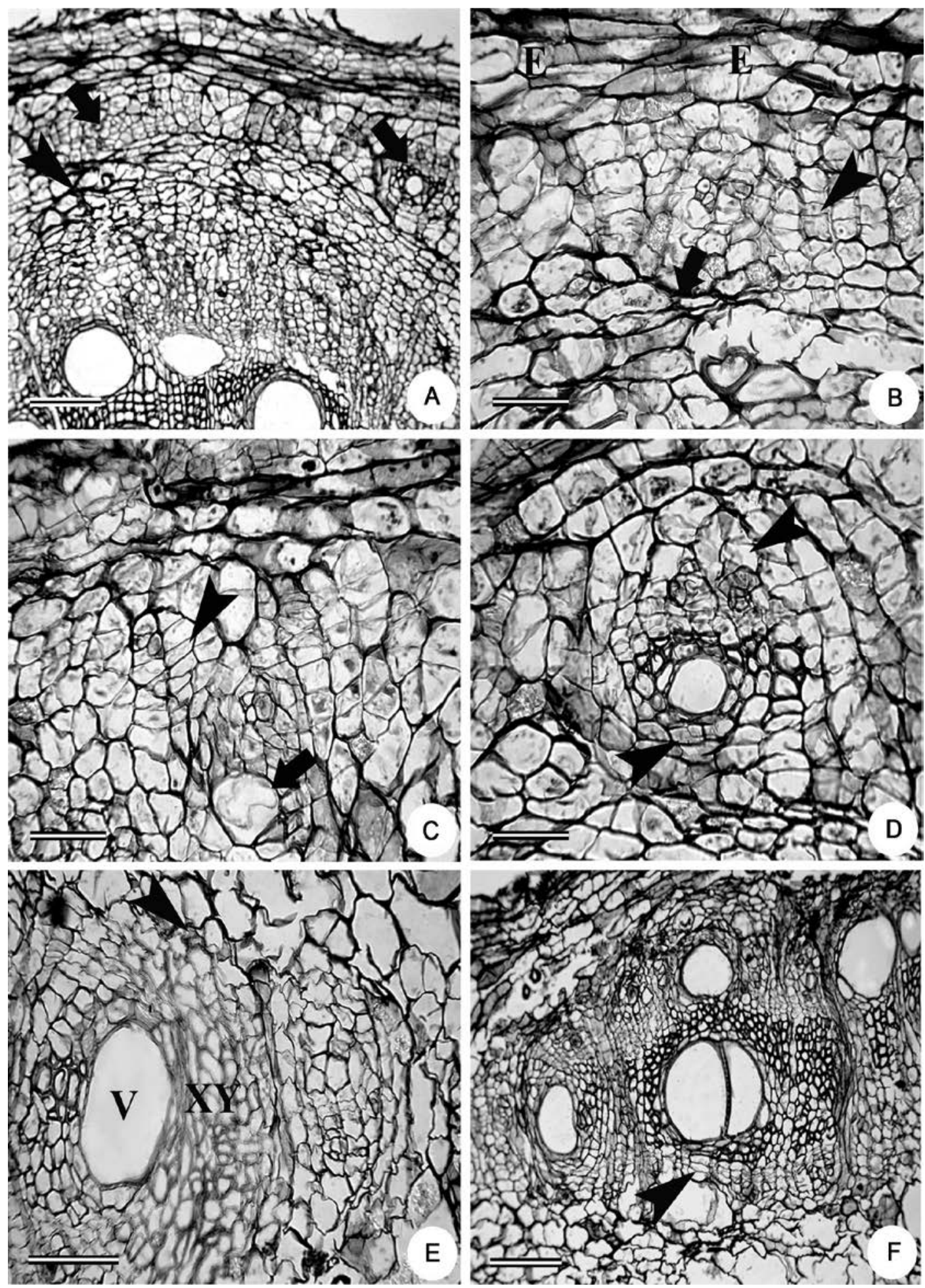

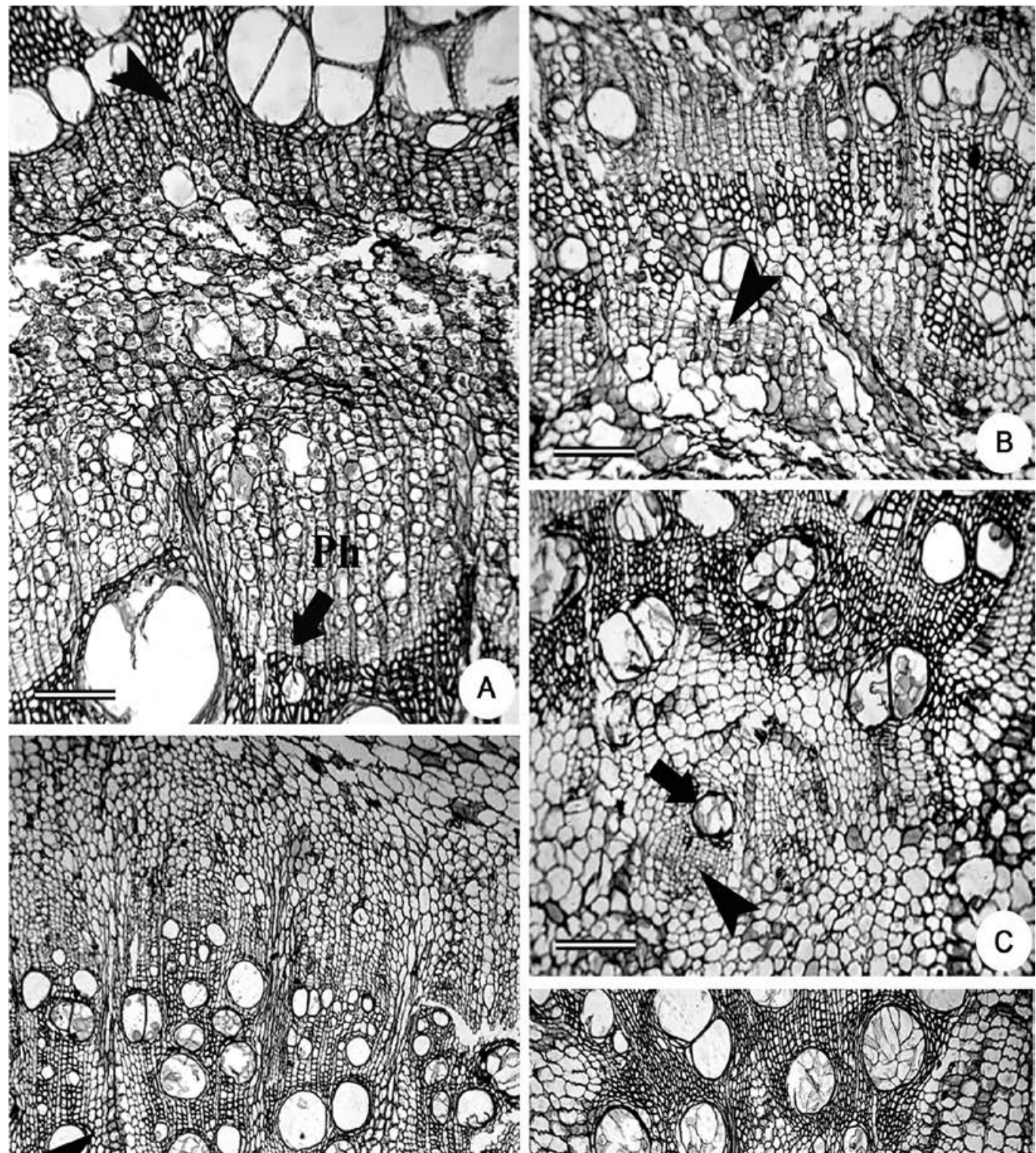
at $x$

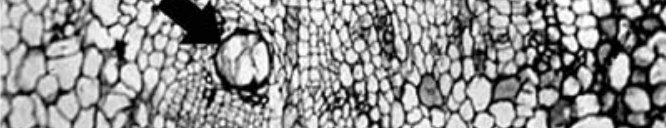
(2)

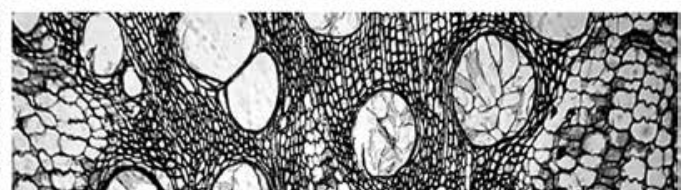

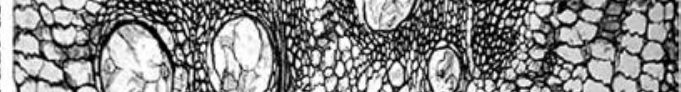

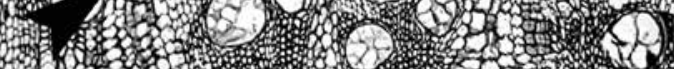
37 . 2.

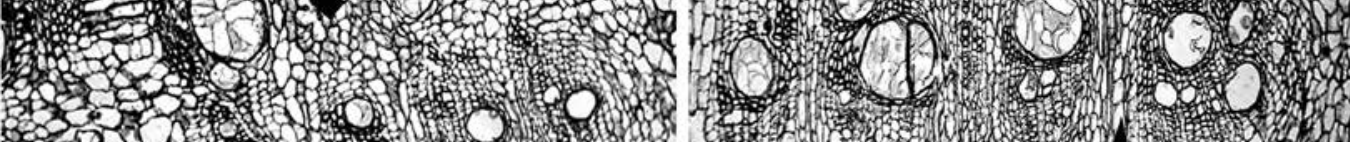
\%3 2.

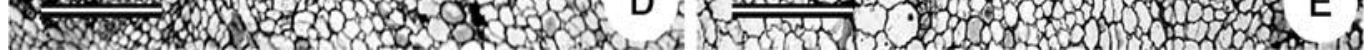


secondary xylem and phloem as alternate rings in which secondary xylem is produced internally and phloem is formed externally (i.e., concentric type); (ii) a single cambial ring producing secondary phloem bidirectionally for a short period (interxylary phloem) and recommencing its normal activity to form secondary xylem internally and phloem externally (foraminate type); and (iii) normal cambium initiating as a single ring and producing secondary xylem centripetally and secondary phloem centrifugally, and forming a stem conformation other than cylindrical. The formation of successive cambia in Ipomoea turbinata does not fit any of the classifications proposed so far, because every alternate cambium produces xylem centrifugally and phloem centripetally. The occurrence of successive cambia along with other variant types has long been reported in different species of the Convolvulaceae (Hallier 1893; Pfeiffer 1926; Pant \& Bhatnagar 1975; Lowell \& Lucansky 1990; Carlquist \& Hanson 1991; Rajput et al. 2008, 2013; Patil et al. 2009; Terrazas et al. 2011), but for Ipomoea turbinata there is virtually no published information detailing the pattern of secondary growth and stem thickening.

Successive cambia occur in 30 dicotyledonous families (Carlquist 2001), 15 of which have lianoid taxa (Carlquist 1991); successive cambia are much better represented in scandent dicotyledons than in other growth forms. These families are scattered among the dicotyledons. The Convolvulaceae are one family in which the first ring of cambium remains actively functional for a definite period. Then it produces a new ring of cambium from the pericycle (Lowell \& Lucansky 1990; Rajput et al. 2008, 2014; Patil et al. 2009; Terrazas et al. 2011). The newly initiated cambium produces secondary xylem centripetally and phloem centrifugally. In I. hederifolia the first successive ring of cambium originates in a manner similar to that described here in I. turbinata. Pant and Bhatnagar (1975) reported similar development in other species of Ipomoea and Argyreia Lour. After initiation of the first successive cambium, subsequent cambia originate from thin-walled parenchyma cells located outside the phloem produced by the newly initiated cambium (Rajput et al. 2008, 2014). I observed a similar pattern of successive cambia initiation. A concept proposed by Carlquist $(2001,2004,2007)$ posits that the first successive cambium is normal but thereafter the development of further successive cambia occurs by tangential divisions in cortical parenchyma cells (termed 'lateral meristem' in 2004 and 'master cambium' in 2007). In I. turbinata, prior to the complete development of a new cambium, parenchyma cells located outside the secondary phloem divide tangentially and form a group of cells. From this, cells on the inner side differentiate into conjunctive tissue while the outer cells become meristematic and behave as a cambium, differentiating secondary xylem and phloem. This process is in accord with the 'master cambium' concept proposed by Carlquist (2004, 2007), but this cambium forms as small segments and not as a continuous ring. Moreover, the cells from which the first successive cambium initiates are located inside the pericycle, and it does not form from cortical cells. The pericyclic origin of successive cambia has been reported in other species of Ipomoea (Pant \& Bhatnagar 1975; Lowell \& Lucansky 1986, 1990; Patil et al. 2009; Rajput et al. 2008, 2014; Terrazas et al. 2011).

Species with successive cambia are always reported to produce secondary xylem centripetally and phloem centrifugally. An unexpected finding of the present study is the inverse action

Fig. 3. Transverse view of secondary xylem of Ipomoea turbinata Lag., showing different stages of cambial initiation. A - Portion of xylem between two successive rings of xylem, showing functionally normal (arrow) and inverse cambium (arrowhead); $\mathrm{Ph}$ - phloem. B - Initiation of functionally inverse cambium (arrowhead). Note the continuous ring of xylem. C - One of the xylem rings, showing small segment of cambium producing xylem centrifugally (arrow) and phloem centripetally (arrowhead). D - Outermost successive ring of xylem in mature stem, showing thick-walled xylem elements (arrow) separated by thin-walled parenchyma (arrowheads). Note the similar behaviour of inverse cambium on its inner margin. E - Enlarged view of D, showing inverse cambium initiating as small segments in which every alternate segment produces conducting elements of xylem and phloem alternating with thin-walled parenchyma cells (arrowheads). Scale bars: A-C = $300 \mu \mathrm{m} ; \mathrm{D} \& \mathrm{E}=500 \mu \mathrm{m}$. 


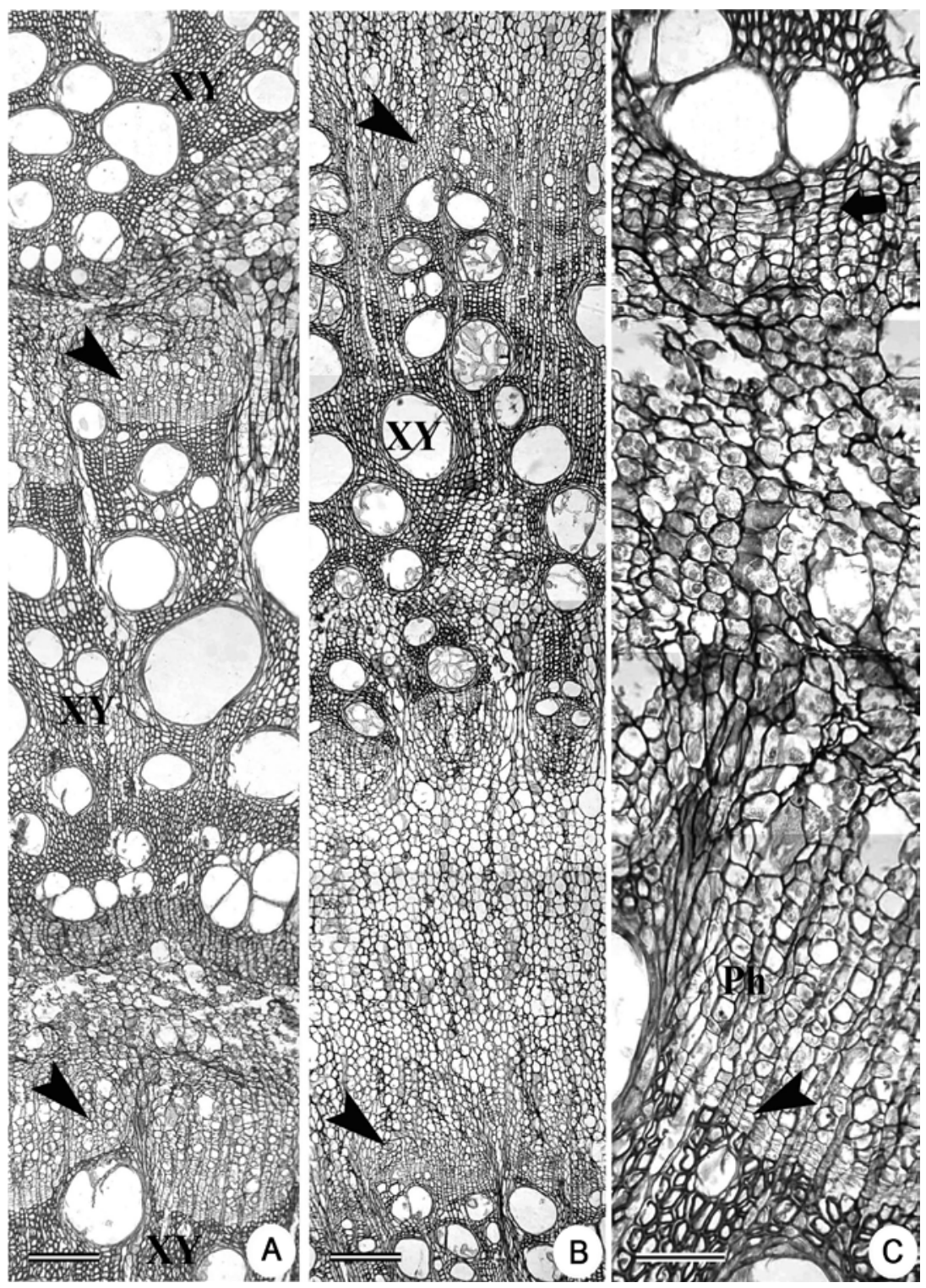

Fig 4. Transverse view of mature stem of Ipomoea turbinata Lag., showing successive rings of xylem alternating with phloem. A - Innermost three successive rings of secondary xylem (XY) in mature stem (arrowhead indicates secondary phloem). B - Outermost successive rings of secondary xylem (XY) in mature stem. Arrowhead indicates secondary phloem. C - Enlarged view of A (lower right corner), showing functionally normal (arrowhead) and inverse cambium (arrow); $\mathrm{Ph}=$ phloem. Scale bars: $\mathrm{A} \& \mathrm{~B}=300 \mu \mathrm{m} ; \mathrm{C}=100 \mu \mathrm{m}$.

of the cambium, which differs from that of other dicotyledons. Similar inverse cambia in the form of small segments have been reported in I. hederifolia and I. pes-caprae (Rajput et al. 2008; 2014) and in I. arborescence (Terrazas et al. 2011).
To my knowledge, the type of cambial variant noted in I. turbinata has been reported in no species except I. hederifolia and I. pes-caprae. The occurrence of such inverse cambia was reported in Ericybe coccinea (F. M. Bailey) Hoog., 
Operculina palmeri (Wats.) Howe and Stictocardia benaviensis (Vatke) H. Hall. (Carlquist \& Hanson 1991), but these reports were not based on an examination of fresh samples, and the initiation patterns were not examined. In all the above-mentioned species, cambial action is reported to produce only a few xylem derivatives centrifugally and extensive phloem centripetally. It is not clear if such a process is aimed at forming only secondary phloem, nor why only a few secondary xylem derivatives are formed. The initiation and development of inverse cambia follow a pattern of origin similar to that of functionally normal cambia, except for their inverse orientation.

The Convolvulaceae are also characterised by the presence of intraxylary phloem, and are one of the 19 families in which the occurrence of intraxylary phloem is reported (Carlquist 2001). Seven of these 19 families have climbing taxa (Carlquist \& Hanson 1991). In the Convolvulaceae, cambium (termed 'internal cambium') initiates between the intraxylary phloem and primary xylem (Rajput et al. 2008, 2014; Terrazas et al. 2011; Carlquist et al. 2013). This internal cambium produces secondary phloem, often in large quantities, on its inner side. Ipomoea turbinata forms similar cambium which produces a quantifiable amount of intraxylary phloem. The formation of similar intraxylary phloem has also been reported in Acanthosicyos horridus Welw. (Carlquist 1992). As in Acanthosicyos, more intraxylary phloem than xylem derivatives forms in I. turbinata. In thicker stems a larger amount of xylem accumulates, with wider vessels and narrow vessels along with xylem fibres.

Fewer xylem derivatives are produced by inverse cambia, but structurally the xylem produced from functionally normal and from inverse cambia is similar. It is composed of wider and fibriform vessels, fibres, and ray and axial parenchyma cells. The vessel dimorphism in I. turbinata is characteristic of a climbing habit and is reported in other species of Convolvulaceae (Carlquist \& Hanson 1991; McDonald 1992; Carlquist 2001; Rajput et al. 2014). Vessel dimorphism is a term applied to the presence of both wide and narrow vessels (Carlquist 1981). Fibriform vessels are considered to be as effective as tracheids in protecting against air embolisms; far fewer embolisms form in narrow vessels than in wider ones (Woodworth 1935; Ellmore \& Ewers 1985). The occurrence of fibriform vessels in the Convolvulaceae and other lianas may furnish an additional conductive system similar to tracheids (Ayensu \& Stern 1964; Carlquist 1991).

The occurrence of a thin-walled unlignified band of parenchyma (also termed 'conjunctive tissue') followed by each xylem ring in I. turbinata may be associated with its scandent habit, providing stem flexibility and protection against stem twisting and bending. One potential benefit claimed for such a conformation is protection of vessels from damage during torsion in liana stems (Schenck 1893; Carlquist 1975; Fisher \& Ewers 1989; Carlquist \& Hanson 1991; Rowe et al. 2004). Protection from damage is a better strategy than repair of damage (Fisher \& Ewers 1989; Carlquist \& Hanson 1991). Water storage is another potential function proposed for the presence of a large parenchyma zone in a liana stem (Carlquist et al. 2013). The presence of parenchymatous tissue in plants with successive cambia is correlated with removal of embolisms, since they store a massive amount of starch. Starch can be converted to sugars to remove an embolism (Carlquist et al. 2013).

In this study I found that in Ipomoea turbinata the first successive cambial ring initiates from pericyclic derivatives. Further cambia originate from parenchyma cells located outside the phloem formed by the previous cambium. These parenchyma cells may be undifferentiated derivatives of pericyclic cells located on the outer margin of the previous cambium. Conjunctive tissue between successive rings originates at the time a new cambium is initiated, and is not the product of the cambium. Functionally inverse cambia initiate from similar derivatives of the previous cambium, located on the inner margin of the secondary xylem. Vessel dimorphism is characteristic for the climbing habit. It ensures a sufficient amount of the water required by a large crown. The fibriform vessels may play a crucial role in providing protection against air embolisms. The structure 
of secondary xylem is the same in the xylem produced by both cambial types. The functional role of the inverse orientation remains unknown and needs further study.

ACKNOWLedGemenTs. I thank Dr. Jan J. Wójcicki and the anonymous reviewers for their useful comments and suggestions. Financial support for this work was provided by the Science and Engineering Research Board (SERB) of the Government of India.

\section{REFERENCES}

Ayensu E. S. \& Stern W. L. 1964. Systematic anatomy and ontogeny of the stem in Passifloraceae. Contr. U.S. Natl. Herb. 34: 45-73.

Berlyn G. P. \& Miksche J. P. 1976. Botanical Microtechnique and Cytochemistry. The Iowa State University Press, Ames, Iowa.

CARLquist S. 1975. Ecological Strategies of Xylem Evolution. University of California Press. Berkeley.

Carlquist S. 1981. Wood anatomy of Nepanthaceae. Bull. Torrey Bot. Club 108: 324-330.

CARLQUist S. 1991. Anatomy of vines and lianas: a review and synthesis. In: F. E. Putz, H. A. Mooney \& S. H. Bullock (eds), The Biology of Vines. Cambridge University Press, Cambridge.

CARLQUist S. 1992. Wood anatomy of selected Cucurbitaceae and its relationship to habit and systematics. Nord. J. Bot. 12: $347-355$.

CARLquist S. 2001. Comparative Wood Anatomy: Systematic, Ecological and Evolutionary Aspects of Dicotyledon Wood. Springer, Berlin, Heidelberg.

CARlquist S. 2004. Lateral meristem, successive cambia and their products: a reinterpretation based on roots and stems of Nyctaginaceae. Bot. J. Linn. Soc. 146: 129-143

CARLquist S. 2007. Successive cambia revisited: ontogeny, histology, diversity, and functional significance. J. Torrey Bot. Soc. 134: 301-332.

CARLQuist S. 2013. Interxylary phloem: Diversity and functions. Brittonia 65: 477-495.

Carlquist S. \& Hanson M. A. 1991. Wood and stem anatomy of Convolvulaceae: a survey. Aliso 13: 51-94.

Carlquist S., Hansen B. F., Iltis H. H., Olson M. E. \& Geigr D. L. 2013. Forchhammeria and Stixis (Brassicales): Stem and wood anatomical diversity, ecological and phylogenetic significance. Aliso 31: 59-75.

Chalk L. \& Chattaway M. M. 1937. Identification of woods with included phloem. Trop. Woods 50: 1-31.
Ellmore G. S. \& Ewers F. W. 1985. Hydraulic conductivity in trunk xylem of elm, Ulmus americana. I.A.W.A. Bull. N.S. 6: 303-307.

Fisher J. B. \& Ewers F. W. 1989. Wound healing in the stems of lianas after twisting and girdling injury. Bot. Gaz. 150: 251-265.

Fisher J. B. \& EwERs F. W. 1991. Structural responses to stem injury in vines. In: F. E. Putz \& H. A. Mooney (eds), The Biology of Vines, pp. 99-124. Cambridge University Press, Cambridge.

Hallier H. 1893. Versuch einer natürlichen Gliederung der Convolvulaceen auf morphologischer und anatomischer Grundlage. Bot. Jahrb. Syst. 16: 453-591.

Johansen D. A. 1940. Plant Microtechnique. McGraw Hill, New York.

LOWELl C. \& LuCANSKY T. W. 1986. Vegetative anatomy and Morphology of Ipomoea hederifolia (Convolvulaceae). Bull. Torrey Bot. Club 113: 382-397.

Lowell C. \& LuCANSKy T. W. 1990. Vegetative anatomy and morphology of Ipomoea quamoclit (Convolvulaceae). Bull. Torrey Bot. Club 117: 232-246.

MCDONALD J. A. 1992. Evolutionary implications of typical and anomalous secondary growth in arborescent Ipomoea (Convolvulaceae). Bull. Torrey Bot. Club 119: 262-267.

Metcalfe C. R. \& Chalk L. 1950. Anatomy of the Dicotyledons. Clarendon Press, Oxford.

Obaton M. 1960. Les lianes ligneuses a structure anormale des forets dense d'afrique occidentale. Ann. Sci. Nat., Bot. 12(1): 1-220.

Pant D. D. \& Bhatnagar S. 1975. Morphological studies in Argyreia Lour. (Convolvulaceae). Bot. J. Linn. Soc. 70: 45-69.

Patil V. S., Rao K. S. \& Rajput K. S. 2009. Development of intraxylary phloem and internal cambium in Ipomoea hederifolia (Convolvulaceae). J. Torrey Bot. Soc. 136: 423-432.

Pfeiffer H. 1926. Das abnorme. Dickenwachstum. Handbuch der Pflanzenatomie. 9. Borntraeger, Berlin.

Rajput K. S., Rao K. S. \& Patil U. G. 2006. Stem anatomy of Dolichos lablab Linn. (Fabaceae): origin of cambium and reverse orientation of vascular bundles. Flora 201: 65-71.

Rajput K. S., Raole V. M. \& Gandhi D. 2008. Radial secondary growth, formation of successive cambia and their products in Ipomoea hederifolia L. (Convolvulaceae). Bot. J. Linn. Soc. 158: 30-40.

Rajput K. S., Romeiro D., Longui E. L. \& Marcati C. R. 2012a. Development of successive cambia and structure of wood in Gallesia integrifolia (Spreng.) Harms (Phytolaccaceae). Trees 26: 1943-1950.

Rajput K. S., Nunes O. M., Brandes A. F. N. \& Tamaio N. 2012b. Development of successive cambia and pattern of secondary growth in the stem of the Neotropical liana 
Rhynchosia phaseoloides (Sw.) DC. (Fabaceae). Flora 206: 607-614.

Rajput K. S., Patil V. S. \& Rao K. S. 2013. Wood anatomy and the development of interxylary phloem of Ipomoea hederifolia Linn. (Convolvulaceae). J. Pl. Growth Regulat. 32: $654-662$

Rajput K. S., Patil V. S. \& Rao K. S. 2014. Multiple cambia and secondary xylem of Ipomoea pes-caprae (L.) R. Br. (Convolvulaceae). Acta Bot. Gallica 161: 13-19.

Robert E. M. R., Schmitz N., Boeren I., Driessens T., Herremans K., Mey J. D., Casteel E. V., Beeckman H. \& KoEdam N. 2011. Successive cambia: a developmental oddity or an adaptive structure? PLOS ONE 6: e16558. doi:10.1371/journal.pone.0016558

Rowe N., IsNARD S. \& SPECK T. 2004. Diversity of mechanical architectures in climbing plants: An evolutionary perspective. J. Pl. Growth Regulat. 23: 108-128.
SCHENCK H. 1893. Beiträge zur Biologie und Anatomie der Lianen, im Besonderen der in Brasilien einheimischen Arten. II. Beiträge zur Biologie der Lianen. Bot. Mitt. Tropen 5: 1-271.

Schnitzer S. A. \& Bongers F. 2011. Increasing liana abundance and biomass in tropical forests: emerging patterns and putative mechanisms. Ecology Letters 14: 397-406.

Terrazas T., Aguilar-Rodríguez S. \& Ojanguren C. T. 2011. Development of successive cambia, cambial activity, and their relationship to physiological traits in Ipomoea arborescens (Convolvulaceae) seedlings. Amer. J. Bot. 98: $765-774$.

WoOdworth R. H. 1935. Fibriform vessel members in the Passifloraceae. Trop. Woods 41: 8-16. 